\title{
СИНТЕЗ И ПРОТИВООПУХОЛЕВАЯ АКТИВНОСТЬ ФЕОСФЕРИДА А, МОДИФИЦИРОВАННОГО АЗОТСОДЕРЖАЩИМИ ЦИКЛИЧЕСКИМИ ГРУППИРОВКАМИ
}

\section{С.А. Захаренкова', В.В. Абзианидзе', Д.С. Супонина', Н.И. Моисеева², Л.С. Чистый' ${ }^{1}$ Д.В. Криворотов ${ }^{1}$, Ю.Г. Тришин ${ }^{3}$}

${ }^{1}$ Научно-исследовательский институт гигиены, профпатологии и экологии человека Федерального медико-биологического агентства, 188663, Ленинградская обл.,

Всеволожский р-н, гп. Кузьмоловский, Россия; e-mail: vvaavv@mail.ru.

${ }^{2}$ Н.Н. Национальный медицинский исследовательский онкологический центр им. Блохина, 115478, Москва, Российская Федерация.

${ }^{3}$ Санкт-Петербургский государственный университет промышленных технологий и дизайна, 198095, Санкт-Петербург, Россия.

DOI: 10.19163/MedChemRussia2021-2021-161

E-mail: sofya.zakharenkova@gmail.com

Синтезированы новые производные 2-7,9,10 на основе природного цитостатического антибиотика феосферида A [1] и оценена их противораковая активность.

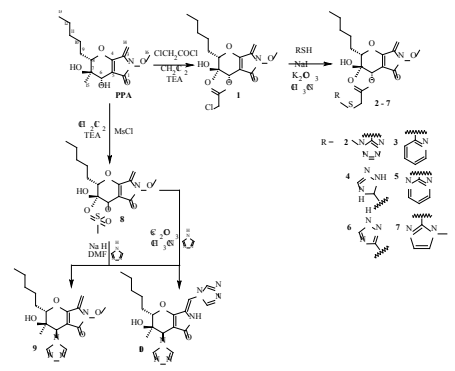

\begin{tabular}{|l|c|c|c|c|c|c|c|}
\hline \multirow{2}{*}{ Соединение } & \multicolumn{4}{|c|}{ Адгезивные клеточные культуры, IC50 } & \multicolumn{2}{c|}{$\begin{array}{c}\text { Суспензионные клеточные } \\
\text { культуры, IC50 ( } \mu \mathrm{M})\end{array}$} \\
\cline { 2 - 8 } & HCT-116 & MCF-7 & PC3 & A549 & HEK293 & NCI-H929 & $\begin{array}{r}\text { RPMI } \\
\mathbf{8 2 2 6}\end{array}$ \\
\hline PPA & 48,0 & 19,0 & 35,0 & 42,0 & 10,0 & 1,3 & 3,2 \\
\hline 2 & 6,5 & 4,9 & 20,4 & 15,0 & 7,4 & 2,9 & 6,3 \\
\hline 4 & 7,6 & 3,4 & 9,8 & 19,0 & 6,7 & 1,0 & 2,2 \\
\hline Этопозид & 21,0 & 8,9 & 27,0 & 658,3 & 1,1 & 1,4 & 7,2 \\
\hline
\end{tabular}

Наиболее активными оказались вещества 2 и 4 по сравнению с исходным феосферидом А и контрольным веществом-этопозидом.

\section{Литература}

1. K. N. Maloney, W. Hao, J. Xu, J. Gibbons, J. Hucul, D. Roll, S. F. Brady, F. C. Schroeder, J. Clardy, Org. Lett., 2006, 8, 4067.

$$
-161-
$$

